\title{
Mensaje del director
}

La publicación de este número de Estudios Internacionales, el primero del presente año, coincide con el cambio de dirección de la revista en el marco de su prolongada trayectoria y de su tradición editorial. Consecuentemente con los principios y la orientación que le han dado sus fundadores y sucesivos directores, asumimos este desafío con entusiasmo, resueltos a consagrar nuestros mejores esfuerzos a continuar aportando a una tarea editorial y académica en el ámbito de las relaciones internacionales, que en forma ininterrumpida y por casi medio siglo ha llevado adelante el Instituto de Estudios Internacionales de la Universidad de Chile.

En esta oportunidad corresponde dejar constancia de la muy destacada gestión del Director saliente, profesor Manfred Wilhelmy. Durante ella y con la estrecha y diligente colaboración de la Editora, profesora Rose Cave, Estudios Internacionales mantuvo su prestigio y reconocimiento intelectual, ingresando a la categoría de revista indizada en SciELO. Puede decirse entonces que en atención a sus méritos la revista cumplió cabalmente con los exigentes estándares editoriales de otros medios de comunicación especializados.

Confiamos en que, con el mismo espíritu y perseverando en la senda recorrida a partir de su creación, Estudios Internacionales seguirá acrecentando su presencia y valoración y accederá a otros medios de indización reconocidos. De esta manera, reafirmará sus niveles de excelencia editorial en la difusión de investigaciones multidisciplinarias y de opiniones relevantes en el plano internacional, tanto a nivel mundial como en América Latina.

Entendemos que la tarea editorial de una publicación como Estudios Internacionales solo puede cumplirse mediante la labor mancomunada de un grupo especializado, persistente y muchas veces anónimo. Por ello, corresponde expresar nuestro reconocimiento al equipo profesional de la revista, a su Comité Editorial y de manera especial al director del Instituto de Estudios Internacionales, que le ha otorgado permanente respaldo. Asimismo, deseamos destacar y agradecer la importante, oportuna y desinteresada contribución 
académica y profesional de evaluadores y colaboradores de la revista, cuyos aportes son fundamentales para el cumplimiento de sus propósitos.

Conscientes de nuestra responsabilidad en la tarea de orientar las líneas de acción de nuestra revista, estamos dispuestos a empeñarnos a fondo por lograr los objetivos que la nueva realidad internacional le exige a una publicación de esta naturaleza. Aprovechamos la oportunidad para formular una cordial invitación a nuestros colaboradores antiguos y a los que adhieran en el futuro a nuestra acción para acompañarnos en esta tarea. $\mathrm{Al}$ mismo tiempo, hacemos extensiva esta convocatoria a instituciones y universidades, así como a académicos y profesionales que a través de nuestras páginas deseen dar a conocer los resultados de trabajos de investigación y opiniones relevantes susceptibles de publicar y darlos a conocer en distintas latitudes del mundo.

Finalmente, deseamos expresar nuestro reconocimiento al público lector de la revista, que cumple una función fundamental en el desarrollo y vigencia de Estudios Internacionales. Gracias a sus ideas, comentarios y críticas podremos señalar acertadamente el rumbo de nuestra acción futura.

Prof. José A. Morandé Lavín Director 